\title{
Rancang Bangun Data Warehouse Dan Perangkat Analitik Sebagai Penunjang Strategi Promosi ( Studi Kasus Universitas Banten Jaya )
}

\author{
Ma'sum ${ }^{1}$ \\ ${ }^{1}$ Dosen Fakultas Ilmu Komputer Universitas Banten Jaya \\ Jl. Ciwaru Raya No. 2, Kota Serang - Banten \\ Email:masum.unbaja@gmail.com
}

\begin{abstract}
ABSTRAK
Peningkatan jumlah perguruan tinggi baik negeri maupun swasta telah menciptakan persaingan yang kompetitif antar perguruan tinggi. Upaya peningkatan jumlah pendaftar pada saat penerimaan mahasiswa baru setiap tahunnya. Perguruan tinggi memerlukan alat bantu analisis yang dapat meningkatkan strategi promosi dan promosinya terhadap calon mahasiswa Universitas Banten Jaya belum memiliki sistem informasi yang dapat menunjang kebutuhan tersebut, karena data histori yang ada pada transaksi pendaftaran mahasiswa baru tidak dapat langsung diolah menjadi informasi yang dapat menunjang strategi promosi.

Perancangan data warehouse dan perangkat analitik yang digunakan sebagai alat untuk menunjang strategi penerimaan mahasiswa baru. Dengan cara mengumpulkan dan membersihkan data sumber yang kemudian dilakukan Extract, Transform, Load kedalam sebuah database relasional dan kemudian membuat aplikasi perangkat analitik yang dapat mengubah data tersebut menjadi tampilan (visualisasi) yang mudah untuk dianalisa sebagai penunjang strategi promosi.

Rancang Bangun Data Warehouse dan perangkat analitik yang dihasilkan dapat menampilkan visualisasi jumlah pendaftar per tahun akademik, perkota asal pendaftar, per sekolah asal pendaftar, per penghasilan orang tua pendaftar, perjurusan yang dipilih pendaftar (tren).Dan fitur-fitur lain yang dapat menunjang dalam melakukan strategi promosi.
\end{abstract}

Kata kunci :Data Warehouse, Perangkat Analitik, Strategi Promosi, Perguruan Tinggi

\begin{abstract}
An increasing number of universities both state and private has created a competitive competition between universities. Efforts to increase the number of applicants at the time of admission of new students every year, universities are in need of analysis tools that can enhance the promotion and promotion strategies to prospective students. Universitas Banten Jaya not have information systems that can support those needs, because the historical data available on the new student enrollment transaction can not be directly processed into information that can support support promotion strategies.

This study discusses the design of data warehouse and analytic tools that are used as a tool to support the new admissions strategy. By collecting and clean the data source and then carried extract, transfom, load into a relational database and then make the application of analytical tools that can transform this data into the display (visualization) that is easy to be analyzed to support promotion strategies.

Data warehouse and analytic tools supporting the promotion strategy Universitas Banten Jaya. Prototype data warehouse and analytic tools can display the resulting visualization number of applicants per academic year, per $h$ me $t$ wn registrars, registrants per home school, parents income per regis rant, per department were selected registrant (trend). And other features that can support in conducting promotional strategy.
\end{abstract}

Keyword : Data Warehouse, Analytic tool, Promotion Strategy, College 


\section{PENDAHULUAN}

Pertumbuhan jumlah perguruan tinggi yang sangat signifikan dan era perubahan yang begitu cepat merupakan sebuah tantangan besar bagi institusi perguruan tinggi.Sebuah institusi atau lembaga harus secara sistematis membedakan merk dan keunggulannya serta menerapkan suatu strategi promosi.

Berdasarkan data yang didapat dari bagian Akademik dan Kemahasiswaan Universitas Banten Jaya. Salah satu penyebab utama dari rendahnya jumlah pendaftar adalah strategi promosi yang belum tepat dalam menentukan target pasar Sekolah Lanjutan Tingkat Atas (SLTA) wilayah-wilayah yang potensial, target pasar menjadi bagian pokok dalam strategi promosi bisnis. Hal yang senada dengan pendapat menurut Kotler dan Amstrong yang menyatakan bahwa salah satu penyebab utama konsumen tidak melakukan transaksi pembelian (deal) adalah karena tidak adanya tindakan promosi atau penawaran produk yang tepat sasaran.

Salah satu penyebab utama dari rendahnya jumlah pendaftar adalah strategi promosi yang belum dapat menentukan target pasar sekolah-sekolah lanjutan tingkat atas, wilayah-wilayah yang potensial. Target pasar menjadi bagian pokok dalam strategi promosi bisnis, hal ini senada dengan pendapat Kotler \& Amstrong yang menyatakan bahwa salah satu penyebab utama konsumen tidak melakukan transaksi pembelian adalah karena tidak adanya tindakan promosi atau penawaran produk yang tepat sasaran.

Untuk berhasil dalam persaingan pasar, sebuah perusahaan, lembaga atau institusi mengetahui bagaimana cara mengolah dan memanfaatkan informasi pemasaran. Jika sebuah institusi dapat melakukanhal tersebut, maka akan mendapatkan pelanggan baru dan membantu memberikan nilai yang lebih baik kepada pelanggan serta mengetahui apa yang dibutuhkan pelanggan.

Menyikapi permasalahan tersebut tentunya dibutuhkan upaya peningkatan jumlah pendaftar mahasiswa baru pada setiap tahunnya yang dapat ditempuh dengan cara meningkatkan strategi promosi pada daerah-daerah yang potensial tempat tinggal para calon pendftar. Upaya peningkatan strategi promosi pada daerah-daerah yang potensial perlu diterjemahkan dalam keputusan-keputusan yang strategis oleh kepala bagian akademik dan kemahasiswaan untuk memperbaiki strategi promosi pada saat penerimaan mahasiswa baru.

Masalah lainnya yang tidak kalah penting adalah sampai saat ini Universitas Banten Jaya belum memiliki sebuah sistem yang dapat digunakan untuk menunjang pengambilan keputusan yang berkaitan dengan strategi promosi.Sistem informasi akademik dan sistem informasi penerimaan mahasiswa baru yang ada pada Universitas Banten Jaya hanya berfungsi sebagai penunjang kegiatan operasional akademik sehingga belum menyajikan informasi yang dapat dijadikan dasar dalam pengambilan keputusan yang berkaitan dengan strategi promosi tersebut. Penelitian tentang pemasaran yang dilakukan pada tahun 2013 mengemukakan bahwa informasi yang disajikan dengan menggunakan teknik data warehouse pemasaran produk akan membantu pimpinan/pengambil keputusan dalam proses evaluasi dan perencanaan. Serta membantu lembaga atau institusi dalam mencermati trend produk yang diminati pada masing-masing wilayah pemasaran. Penelitian ini memberikan bukti bahwa bidang pemasaran juga membutuhkan data warehouse sebagai penunjang.

Perancangan dan implementasi datawarehouse menghasilkan intisari/ringkasan dari data mentah berguna dalam mengantisipasi jenis laporan dan permintaan informasi yang dibutuhkan oleh sebuah organisasi. Hal ini akan menunjang pimpinan dalam mengambil keputusan. Hasil implementasi dari penggunaan data warehouse menunjukkan bahwa penggunaan data warehouse digunakan pihak manajemen dalam menunjang strategi marketing. Seperti meningkatkan jumlah penjualan sebuah perusahaan penerbit dan toko buku yang sedang berjalan maupun untuk yang akan datang. 
Mengapa tidak menggunakan database yang ada pada sistem informasi akademik? Atau sistem informasi penerimaan mahasiswa baru? Dengan membuat query data pada database yang sudah ada? Selain kondisi sistem informasi (basis data transaksional) yang ada tidak menyediakan fasilitas yang menunjang strategi promosi serta penelitian-penelitian yang telah dilakukan oleh banyak peneliti yang sudah penulis paparkan.Maka sistem/perangkat analitik penunjang strategi promosi adalah kebutuhan yang mutlak. Perbandingan antara basis data transaksional dan data warehouse yang menjadi alasan kuat mengapa harus menggunakan data warehouse dan perangkat analitik penunjang strategi promosi.

Pentingnya penggunaan data warehouse dapat disederhanakan dan menjelaskan perbedaan mendasar antara database transactional dan data warehouse. Perbedaaan ini meliputi tujuan sistem, pengguna data, validasi data, frekuensi pembaruan data, persyaratan dan historis.Integrasi dan keseimbangan data antara database transactional dan data warehouse.

\begin{tabular}{|c|c|c|}
\hline Perbandingan & Database Transaksional & Data Warehouse \\
\hline Tujuan Sistem & $\begin{array}{l}\text { Mendukung proses } \\
\text { operasional }\end{array}$ & $\begin{array}{l}\text { Mendukung analisis strategi, kinerja, dan } \\
\text { pelaporan yang khusuu }\end{array}$ \\
\hline Penggunaan data & $\begin{array}{l}\text { Menangkap dan memelihara } \\
\text { data }\end{array}$ & Eksploitasi (mengolah) data \\
\hline Validasi data & $\begin{array}{l}\text { Verifikasi data terjadi saat } \\
\text { masuk }\end{array}$ & Verifikasi data terjadi setelah fact \\
\hline $\begin{array}{l}\text { Frekuensi } \\
\text { pembaruan data }\end{array}$ & $\begin{array}{l}\text { Data diperbaharui pada saat } \\
\text { transaksi bisnis terjadi } \\
\text { (misalnya login pendaftaran) }\end{array}$ & $\begin{array}{l}\text { Data diperbarui secara periodik, } \\
\text { dijadwalkan proses beberapa tahun yang } \\
\text { sudah lampau }\end{array}$ \\
\hline $\begin{array}{l}\text { Persyaratan data } \\
\text { historiis }\end{array}$ & Data saat ini & Data historis \\
\hline $\begin{array}{l}\text { Integrasi dan } \\
\text { keseimbangan } \\
\text { data }\end{array}$ & $\begin{array}{l}\text { Data seimbang dalam } \\
\text { lingkup satu sistem misal : } \\
\text { sistem informasi akademik }\end{array}$ & $\begin{array}{l}\text { Data harus terintegrasi dan seimbang dari } \\
\text { beberapa system }\end{array}$ \\
\hline
\end{tabular}

Berdasarkan permasalahan dan kemungkinan solusi yang ada, diperlukan rancang bangun sebuah sistem yang akan memberikan dukungan kepada kepala bagian akademik dan kemahasiswaan. Sebuah sistem yang digunakan untuk meningkatkan strategi promosi yang bertujuan meningkatkan jumlah pendaftar pada masa penerimaan mahasiswa baru setiap tahunnya.

Dalam Data warehouse dikenal metode pendekatan analisis data berupa On-Line Analytical Processing atau disingkat OLAP yang merupakan suatu metode pendekatan untuk menyajikan jawaban dari permintaan proses analisis yang bersifat dimensional secara cepat, berupa desain, aplikasi dan teknologi yang dapat mengoleksi, menyimpan, memanipulasi suatu data kedalam data multidimensi untuk tujuan analisis. OLAP merupakan kunci dari data warehouse dan digunakan untuk menganalisis data dan informasi yang kemudian akan digunakan sebagai dasar dari pengambilan keputusan atau decision support system pada sebuah organisasi atau perusahaan. 
Analisis data telah menjadi kebutuhan penting untuk meningkatkan daya saing sebuah organisasi bisnis atau perusahaan.Pengambilan keputusan bergaya entrepreneur yang cenderung mengandalkan intuisi menjadi kurang relevan ditengah persaingan yang semakin kompleks, sehingga dengan demikian manajemen dapat mengambil keputusan berdasarkan fakta aktual, dan tidak hanya mengandalkan intuisi dan pengalaman kuantitatif saja.

Rancang Bangun Data warehouse dan perangkat analitik penunjang strategi promosi menjadi salah satu tolak ukur tingkat keberhasilan dalam penyelenggaraan penerimaan mahasiswa baru pada tiap tahunnya.

Keuntungan atau kelebihan penerapan solusi business intelligence dengan pendekatan OLAP pada Rancang bangun data warehouse berupa pengumpulan data, menyimpan data, menganalisis data dan menyediakan akses ke data sehingga dapat membantu pengguna dalam mengambil keputusan secara akurat dan cepat dengan melakukan berbagai aktivitas.

Perlu diketahui pemanfaatan dari solusi business intelligence pada universitas telah memberi banyak manfaat dan keuntungan pada mengembangkan suatu sistem pendukung keputusan dalam lingkungan akademik, manajemen kepegawaian dan manajemen keuangan serta pengembangan rencana strategis universitas. Karena solusi business intelligencedapat digunakan dalam mempertimbangkan proses pengambilan keputusan padauniversitas sebagai bagian penting dalam manajemen bisnis yang besar pada dunia pendidikan di Indonesia, hal ini dikarenakan faktor yang mempengaruhi kinerja dan optimalisasi dalam pengelolaan universitas sama halnya dengan seperti yangterlibat dalam proses bisnis pada perusahaan profit pada umumnya.

Pemanfaatan dan penggunaan sistem informasi dalam konteks business intelligence tentunya menggunakan pusat penyimpanan data dan proses penyimpanan serta pengelolaan data berupa data dosen, mahasiswa, kegiatan belajar mengajar, penelitian dan pengabdian pada masyarakat, kepustakaan, keuangan dan lain-lainnya akan semakin bertambah dari tahun ke tahun. Sehingga hal ini diperlukan suatu penyimpanan data ringkasan dari sumber data operasional maupun sumber data transaksional yang ada berupa basisdata data warehouse. Selanjutnya data didalam basisdata data warehouse diolah dan diproses dengan teknologi OLAP yang hasil dari proses tersebut dapat disajikan dan ditampilkan pada visualisai dan berupa laporan analisis statistik berupa grafik dan tabel serta laporan.

Pentingnya informasi untuk mengetahui statistik perkembangan pendaftar tiap tahunnya yang terdapat dalam rancang bangun data warehouse dan perangkat analitik yang dilihat dari sudut pandang informasi eksekutif dan informasi stategis serta aspek lainnya pada periode tertentu, sehingga hal tersebut mendasari penelitian ini.

\section{LANDASAN TEORI}

\section{Data Warehouse}

Data Warehouse atau disingkat DW merupakan basisdata relasional yang didesain lebih kepada querydan analisa dari pada proses transaksi, dan biasanya mengandung history data dari proses transaksi dan bisa juga data dari sumber lainnya. Data Warehouse dapat juga dikatakan sebagai tempat penyimpanan ringkasan dari data historis yang seringkali diambil dari basisdata terpisah departemen, organisasi atau perusahaan (Kimball dan Caserta, 2004).

Menurut Inmon (2002) bahwa data warehousemerupakan koleksi data yang mempunyai sifat berorientasi subyek, terintegrasi, time-variant, dan bersifat tetap dari koleksi data dalam mendukung proses pengambilan keputusan management, proses ini subjectoriented, terintegrasi, waktu yang bervariasi dan permanen. 
Tujuan utama dari pembuatan data warehouse merupakan untuk menyatukan data yang beragam ke dalam sebuah tempat penyimpanan dimana pengguna dapat dengan mudah menjalankan query, menghasilkan laporan, dan melakukan analisis. Salah satu keuntungan yang diperoleh dari keberadaan data warehouseadalah dapat meningkatkan efektifitas pembuatan keputusan.

Dari definisi yang dijelaskan diatas, dapat disimpulkan bahwa data warehouse merupakan basisdata yang saling berinteraksi dan dapat digunakan untuk query dan analisis, bersifat orientasi subyek, terintegrasi, time-variant, tidak berubah (adhoc) yang nantinya digunakan dalam membantu pengambilan keputusan organisasi atau perusahaan oleh pihak pengambil keputusan.

\section{Karakteristik Data Warehouse}

Berikut ini merupakan karakteristik data warehouse (Inmon, 2002) yaitu :

1. Berorientasi Subyek(Subject Oriented) yaitudata warehouse didesain untuk menganalisa data berdasarkan subyek tertentu dalam perusahaan atau organisasi, bukan pada proses atau fungsi aplikasi tertentu. Hal ini dikarenakan kebutuhan dari data warehouse untuk menyimpan data yang bersifat sebagai penunjang suatu keputusan, dari pada aplikasi yang berorientasi terhadap data.Jadi dengan kata lain, data yang disimpan merupakan berorientasi kepada subyek bukan terhadap proses.

2. Terintegrasi (Integrated) yaitudata warehouse dapat menyimpan data yang berasal dari sumber-sumber yang terpisah kedalam suatu format yang konsisten dan saling terintegrasi satu dengan lainnya. Dengan demikian data tidak bisa dipecah-pecah karena data yang ada merupakan suatu kesatuan yang menunjang keseluruhan konsep data warehouse itu sendiri. Syarat integrasi sumber data dapat dipenuhi dengan berbagai cara sepeti konsisten dalam penamaan variabel, konsisten dalam ukuran variabel, konsisten dalam struktur pengkodean dan konsisten dalam atribut fisik dari data.

2. Rentang Waktu (Time-Variant) yaitu seluruh data pada data warehouse dapat dikatakan akurat atau valid pada rentang waktu tertentu. Untuk melihat interval waktu yang digunakan dalam mengukur keakuratan suatu data warehouse, dapat menggunakan cara antara lain yakni :

1. Cara yang paling sederhana merupakan menyajikan data warehouse pada rentang waktu tertentu, misalnya antara 5 sampai 10 tahun ke depan.

2. Cara yang kedua, dengan menggunakan variasi/perbedaan waktu yang disajikan dalam data warehouse baik implisit maupun secara eksplisit dengan unsur waktu dalam hari, minggu, bulan. Secara implisit misalnya pada saat data tersebut diduplikasi pada setiap akhir bulan, atau per tiga bulan. Unsur waktu akan tetap ada secara implisit didalam data tersebut.

3. Cara yang ketiga,variasi waktu yang disajikan data warehouse melalui serangkaian snapshot yang panjang. Snapshot merupakan tampilan dari sebagian data tertentu sesuai keinginan pemakai dari keseluruhan data yang ada bersifat read-only.

4. Non Volatile yaitu data pada data warehouse tidak di update secara real timetetapi di refresh dari sistem operasional secara rutin. Data yang baru selalu ditambahkan sebagai suplemen bagi basisdata itu sendiri dari pada sebagai sebuah perubahan. Basisdata tersebut secara kontinyu menyerap data baru ini, kemudian secara incremental disatukan dengan data sebelumnya. 
Berikut ini merupakan hal-hal yang berkaitan dengan data warehouse dalam penerapan pada sistem business intelligence (Inmon, 2002) yaitu :

1. Data Mart yakni merupakan suatu bagian pada data warehouse yang mendukung pembuatan laporan dan analisa data pada suatu unit, bagian atau operasi pada suatu perusahaan.

2. On-Line Analytical Processing yakni merupakan suatu pemrosesan basisdata yang menggunakan tabel fakta dan dimensi untuk dapat menampilkan berbagai macam bentuk laporan, analisis, query dari data yang berukuran besar.

3. On-Line Transaction Processing yakni merupakan suatu pemrosesan yang menyimpan data mengenai kegiatan operasional transaksi sehari-hari.

4. Dimension Table yakni merupakan tabel yang berisikan kategori dengan ringkasan data detail yang dapat dilaporkan. Seperti laporan laba pada tabel fakta dapat dilaporkan sebagai dimensi waktu yang berupa perbulan, perkwartal dan pertahun.

5. Fact Table yakni merupakan tabel yang umumnya mengandung angka dan data history dimana key (kunci) yang dihasilkan sangat unik, karena key tersebut terdiri dari foreignkey(kunci asing) yang merupakan primarykey (kunci utama) dari beberapa dimensi tabel yang berhubungan.

6. Decision Support System yakni merupakan sistem yang menyediakan informasi kepada pengguna yang menjelaskan bagaimana sistem ini dapat menganalisa situasi dan mendukung suatu keputusan yang baik.

\section{Tugas Data Warehouse}

Ada empat tugas yang bisa dilakukan oleh data warehouse (Kimball dan Caserta, 2004) yaitu :

1. Pembuatan Laporan yakni proses pembuatan laporan merupakan salah satu kegunaan data warehouse yang paling umum dilakukan. Dengan menggunakan query sederhana didapatkan laporan perhari, perbulan, pertahun atau jangka waktu kapan pun yang diinginkan.

2. OLAP yakni dengan adanya data warehouse, semua informasi baik detail maupun hasil summary yang dibutuhkan dalam proses analisa mudah di dapat. OLAP mendayagunakan konsep multidimensional dan memungkinkan para pemakai menganalisa data sampai mendetail, tanpa mengetikkan satupun perintah query.

3. Data Mining yakni merupakan proses untuk menggali pengetahuan dan informasi baru dari data yang berjumlah banyak pada data warehouse, dengan menggunakan kecerdasan buatan (artificial intelligence), statistik dan matematika. Beberapa solusi yang diberikan data mining antara lain yakni :

3.1 Menebak target pasar diaman data mining dapat mengelompokkan (clustering) model-model pembeli dan melakukan klasifikasi terhadap setiap pembeli dan melakukan klasifikasi terhadap setiap pemebeli sesuai dengan karakteristik yang diinginkan.

3.2 Melihat pola beli dari waktu ke waktu dimana data mining dapat digunakan untuk melihat pola beli dari waktu ke waktu.

3.3 Cross-Market Analysis dimana data mining dapat dimanfaatkan untuk melihat hubungan antara satu produk dengan produk lainnya. 
3.4 Profil pelanggan dimana data mining bisa membantu pengguna untuk melihat profil pembeli sehingga dapat diketahui kelompok pembeli tertentu cenderung kepada suatu produk apa saja.

4. Informasi summary dimana data mining dapat membuat laporan summary yang bersifat multidimensi dan dilengkapi dengan informasi statistik lainnya.

Proses Informasi Eksekutif yakni data warehouse dapat membuatringkasan informasi yang penting dengan tujuan membuat keputusan bisnis, tanpa harus menjelajahi keseluruhan data. Dengan menggunakan data warehouse segala laporan telah diringkas dan dapat pula mengetahui segala rinciannya secara lengkap, sehingga mempermudah proses pengambilan keputusan.

Data Warehousemempunyai beberapa elemen penting didalamnya (Mallach, 2000) yaitu :

a. Sumber data atau data source yang digunakan oleh data warehouseyakni basisdata operasional atau transaksional dan sumber data eksternal.

b. Proses extraction, transformation, loading atau ETL dari sumber data ke basisdata data warehouse.

c. Membuat suatu ringkasan atau summaryterhadap data warehousemisalkan dengan menggunakan fungsi agregat.

d. Metadata, menguraikan struktur dan beberapa arti mengenai data, dengan demikian mendukung penggunaan efektif atau tidak efektif dari suatu data.

e. Basisdata data warehouse, basisdata ini berisi data yang detail dan ringkasan data dari data yang ada di dalam basisdatadata warehouse.

f. User, pengguna yang memanfaatkan data warehousetersebut.

\section{OLAP (On-Line Analytical Processing)}

On-Line Analytical Processing atau disingkat OLAP secara mendasar merupakan suatu metode khusus untuk melakukan analisis terhadap data-data yang terdapat dalam media penyimpanan data berupa basisdata dan kemudian dilanjutkan dengan membuat laporan analisis sesuai dengan permintaan para pengguna atau user. Untuk tujuan tersebut data yang berupa informasi dibuat ke dalam format khusus dengan memberikan kelompok atau group terhadap data-data tersebut, hal ini dinamakan dengan model kubus (cube models).

OLAP merupakan teknologi yang memungkinkan seorang analis, manajer dan eksekutif secara bersamaan mengakses data-data secara cepat, konsisten dan interaktif dengan berbagai variasi dan visualisasi tinjauan informasi dimana setiap baris data dapat di transformasikan untuk merefleksikan dimensi perusahaan atau organisasi sehingga mudah dipahami oleh pengguna atau user (Ponniah, 2001).

Berikut karakteristik utama yang terdapat pada On-Line Analytical Processing yakni meliputi :

1. Mendukung pemanfaatan dan penggunaan data warehouse yang memiliki data multidimensional.

2. Menyediakan fasilitas query interaktif dan analisis yang kompleks.

3. Menyediakan fasilitas drill-down untuk memperoleh informasi yang rinci, dan roll-up untuk memperoleh agregat dalam multidimensional.

4. Mampu menghasilkan perhitungan dan perbandingan.

5. Mampu menyajikan hasil dalam bentuk angka-angka yang mudah dimengerti maupun penyajian dalam bentuk grafik.

Data pada OLAP disimpan dalam model multidimensional.Jika pada basisdata relasional terdiri dari dua dimensi, maka pada basis multidimensional terdiri dari banyak dimensi yang dapat dipisahkan oleh OLAP menjadi beberapa sub atribut.OLAP dapat digunakan untuk data miningatau menemukan hubungan antara suatu item yang belum ditemukan. 
Pada basisdata OLAP tidak perlu memiliki ukuran besar seperti data warehouse, karena tidak semua transaksi membutuhkan analisis tren, karena tujuan OLAP menampilkan data dalam sebuah tabel yang dinamis, yang secara otomatis akan meringkas data ke dalam beberapa irisan data yang berbeda-beda dan mengizinkan pengguna atau user untuk secara interaktif melakukan perhitungan dan serta membuat format suatu laporan.

OLAP merupakan proses komputer yang memungkinkan pengguna dapat dengan mudah dan selektif memilih dan melihat data dari sudut pandang yang berbeda-beda. Beberapa aktivitas yang dilakukan OLAP antara lain dapat men-generatequery, meminta laporan yang adhoc, mendukung analisis statistik, analisis interaktif, membangun aplikasi multimedia. Untuk memfasilitasi OLAP ini diperlukan DW dengan sekumpulan tools yang memiliki kemampuan multidimensi. tools ini dapat berupa querytools, spreadsheet, data mining tools, dan data visualisation.

View berhubungan erat dengan OLAP dan data warehouse. Query OLAP biasanya merupakan queryagregat. Seorang analis biasanya menginginkan jawaban cepat untuk query pada sebuah dataset yang sangat besar, dan secara alami memperhatikan perhitungan awal dari view. Secara khusus, operator cube menimbulkan beberapa queryagregat yang berhubungan erat. Hubungan yang ada antara banyak queryagregat yang muncul dari operasi cube tunggal dapat dieksploitasi untuk mengembangkan strategi komputasi awal yang sangat efektif.

Tools untuk membuat laporan tersebut merupakan tabel itu sendiri, yaitu dengan melakukan drag terhadap kolom dan baris. Pengguna atau user dapat mengubah bentuk laporan dan menggolongkannya sesuai dengan keinginan dan kebutuhan pengguna atau user tersebut dan OLAP engine secara otomatis akan mengkalkulasi data yang baru.

Query OLAP dipengaruhi oleh dua hal yaitu structure query language (SQL) dan spreadsheet. Operasi yang umum dalam query OLAP adalah melakukan agregasi pada satu atau lebih dimensi. Berikut jenis-jenis query OLAP yaitu :

1. Roll-Up yakni melakukan agregasi pada level yang berbeda dari hirarki dimensi. Misalnya untuk setiap kota diberikan total penjualan, maka untuk total penjualan tiap propinsi bisa didapatkan dengan menambahkan total penjualan pada semua kota dalam satu propinsi.

2. Drill-Down yakni kebalikan dari Roll-Up. Misalnya untuk setiap propinsi dapat diberikan total penjualan, maka total penjualan tiap kota dapat di Drill-Down.

3. Pivoting yakni melakukan agregasi pada dimensi terpilih. Misalnya jika dilakukan pivoting pada location dan time didapatkan cross-tabulation.

Perancangan atau desain merupakan proses setelah melakukan tahap analisis sistem selesai dilakukan, maka analis sistem telah mendapatkan gambaran dengan jelas apa yang harus dikerjakan. Saatnya bagi analis sistem untuk memikirkan bagaimana membentuk sistem tersebut. Proses ini disebut dengan perancangan sistem atau desain sistem (systems design).

Desain sistem dapat dibagi dalam dua bagian, yaitu desain sistem secara umum dan desain sistem terinci.Desain sistem secara umum disebut juga dengan desain secara makro sedangkan desain sistem terinci disebut juga dengan desain sistem secara fisik atau desain internal (Jogiyanto, 2001).

Dari pengertian diatas mengenai perancangan atau desain sistem, maka desain sistem dapat diartikan sebagai berikut :

a) Tahap setelah analisis dari siklus pengembangan sistem.

b) Pendefinisian dari kebutuhan-kebutuhan fungsional.

c) Persiapan untuk rancang bangun implentasi.

d) Menggambarkan bagaimana suatu sistem dibentuk. 
e) Sistem dibentuk dapat berupa penggambaran, perencanaan dan pembuatan sketsa atau pengaturan dari beberapa elemen yang terpisah ke dalam satu kesatuan yang utuh dan berfungsi.

f) Termasuk menyangkut mengkonfigurasi dari komponen-komponen perangkat lunak dan perangkat keras dari suatu sistem.

Dari pengertian diatas dapat diambil kesimpulan bahwa rancang bangun sistem merupakan prosedur atau proses tahapan yang dilakukan setelah analisis sistem yakni mendefiniskan kebutuhan fungsional, melakukan persiapan implentasi sistem, menggambarkan sistem dibentuk berupa penggambaran, perencanaan dan pembuatan sketsa atau pengaturan dari beberapa elemen yang terpisah ke dalam satu kesatuan yang utuh dan berfungsi serta mengkonfigurasi dari komponen perangkat lunak dan perangkat keras dari suatu sistem, dan kemudian mengimplementasikan penggambaran, perencanaan dan pembuatan sketsa tersebut kedalam kode program yang telah ditentukan atau disiapkan.

Data Warehouse adalah penggabungan dari proses-proses data dan termasuk dalam tujuan untuk mendukung kegiatan bisnis serta analisis dan membuat keputusan.

Pengertian mengenai data warehouse lebih jelasnya diterjemahkan ke dalam gambar

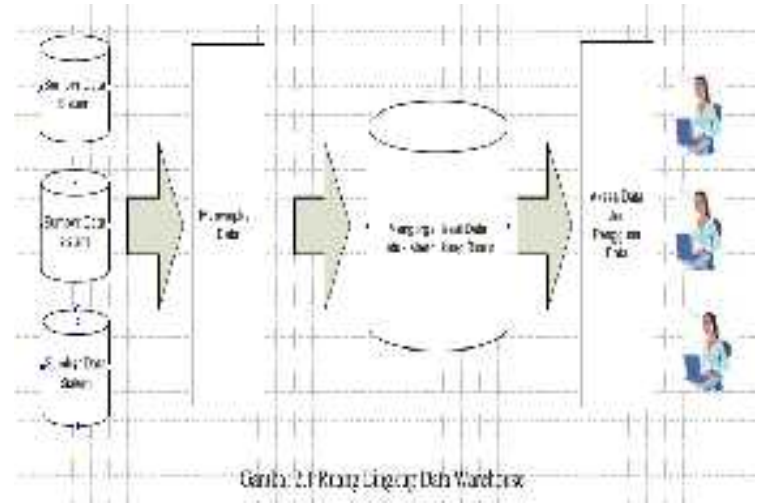

Data warehouse adalah suatu gudang data yang terkenal dipakai untuk mengembangkan arsitektur kecerdasan bisnis (business intelligence) dan sistem pendukung keputusan. istilah data warehouse merupakan kesatuan yang aktifitas perancangan. Menerapkan dan menggunakan suatu data warehouse

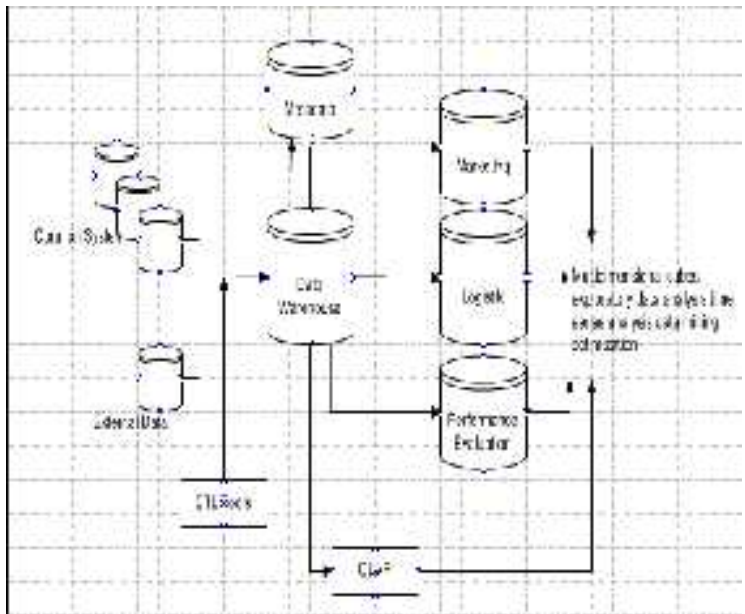

Gambar 2.2 Fungsi dan Arsitektur Data Warehouse

Sedangkan menurut J. Mundy dkk data warehousing and business intelligence adalah cara untuk menyediakan informasi dan alat-alat bantu yang dibutuhkan untuk membuat keputusan bisnis yang strategis [16]. peneliti memberikan kesimpulan data warehouse berguna untuk menunjang pengambilan keputusan. 
Menurut Sarka dkk data warehouse adalah pemusatan data sebuah perusahaan hasil dari pengolah penggabungan. perbaikan dari data masa lampau (historical).

Peneliti lain M. Sethi. mendefinisikan data warehouse adalah koleksi teknologi pendukung keputusan yang mengarah pada memungkinkan eksekutif, manajer dan analisis untuk lebih cepat dan lebih baik dalam mengambil keputusan yang berkaitan dengan informasi sebagai produk dan laporan yang digunakan sebagai hasil pencapaian.

Dari beberapa pengertian tentang data warehouse dapat diambil kesimpulan bahwa data warehouse adalah gudang data yang disalin dan diolah dari basis data transaksi di masa lampau (historical) yang dapat di analisa dengan menggunakan business intelligence sehingga menghasilkan suatu pengetahuan baru yang dapat mempermudah pengambilan keputusan.

Pengembagan data warehouse yang optimal memerlukan tahapan pengembangan yang ideal. sehingga akan dihasilkan data warehouse yang sesuai dengan harapan. pengembangan data warehouse juga menghasilkan keluaran sistem yang bermanfaat untuk menunjang pengambilan keputusan dan analis bisnis yang strategis, hal ini dapat ditunjukan pada gambar 2.3

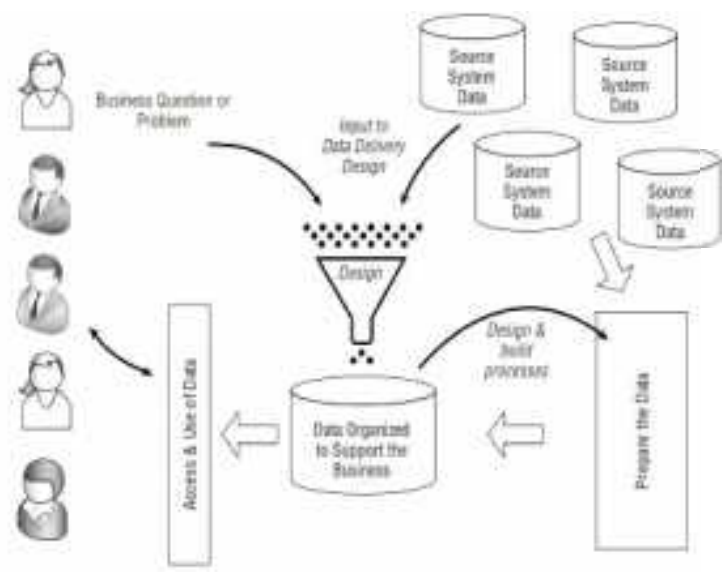

Gambar 2. 3 Tahapan pengembangan dan perancangan data warehouse yang optimal

Pengembangan data warehouse memerlukan langkah-langkah metodologi. Langkahlangkah metodologi tersebut berdasarkan konsep yang diusulkan oleh Kimball yang dikenal dengan Nine Step Methodology seperti pada tabel berikut :

Tabel Nine Step Methodology by Kimball

\begin{tabular}{|c|l|}
\hline Step & \multicolumn{1}{|c|}{ Activity } \\
\hline 1. & Choosing the Process \\
\hline 2. & Choosing the Grain \\
\hline 3. & Identifying and conforming the dimensions \\
\hline 4. & Choosing the Facts \\
\hline 5. & Storing pre-calculations in the fact table \\
\hline 6. & Rounding out the dimension tables \\
\hline 7. & Choosing the duration of the database \\
\hline 8. & Tracking slowly changing dimensions \\
\hline 9. & Deciding the query priorities and the query models \\
\hline
\end{tabular}

1. Choosing the Process

Sebuah proses (fungsi) yang mengacu pada masalah subjek tertentu dalam data mart. Ketika pertama kali membangun data mart yang tepat, sesuai anggaran dan dapat dipakai untuk menjawab permasalahan bisnis yang ada. 


\section{Choosing the Grain}

Menentukan apa yang dijelaskan oleh record dalam tabel fakta.

3. Identifying and conforming the dimensions

Mengidentifikasi dan menyesuaikan dimensi, membuat dimensi yang dapat menjawab pertanyaan tabel fakta. Proses ini membuat data mart mudah dimengerti dan digunakan.

4. Choosing the Facts

Mengidentifikasi tabel fakta yang menentukan fakta-fakta yang dapat digunakan dalam data mart. Semua fakta harus mewakili induk tabel fakta. Contoh : jika induk tabel adalah penjualan maka semua fakta yang kuantitatif harus merujuk pada induk tabel fakta penjualan.

5. Storing pre-calculations in the fact table

Menyimpan pra perhitungan dalam tabel fakta; ketika sebuah tabel fakta telah ditentukan maka setiap fakta harus dikaji ulang untuk dapat melakukan pra calculation. Contoh : pada tabel fakta penjualan terdapat fakta-fakta yang dapat dilakukan pra-perhitungan seperti ; total penjualan, total tagihan.

6. Rounding out the dimension tables

Pada tahapan ini kembali pada tabel dimensi menambahkan informasi selengkap mungkin. Pernyataan harus intuitif dan mudah dipahami oleh pengguna. Tingkat kebergunaan data mart ditentukan oleh lingkup atribut tabel dimensi.

7. Choosing the duration of the database

Memilih durasi atau priode database, menentukan sejauh mana periode tabel fakta bisa melihat beberapa tahun ke belakang, menyesuaikan dengan kebutuhan, kebijakan dan peraturan yang ada pada sebuah institusi. Tahap ini juga berkaitan dengan data lama yang ada dan terkadang menjadi permasalahan pada isi data (record) yang akan berhubungan dengan tahap selanjutnya.

8. Tracking slowly changing dimensions

Merubah atribut dimensi dengan menambahkan atribut alternatif baru sehingga record lama dan baru dapat digunakan secara bersamaan pada record dimensi yang sama. Contoh atribut pelanggan lama dan kota/kabupaten baru akan digunakan pada tabel transaksi historis.

9. Deciding the query priorities and the query models

Pada tahap akhir metodologi ini kita mempunyai suatu desain untuk suatu data mart yang mendukung kebutuhan proses bisnis tertentu dan juga mengijinkan pengintegrasian yang gampang dengan data mart lain. 


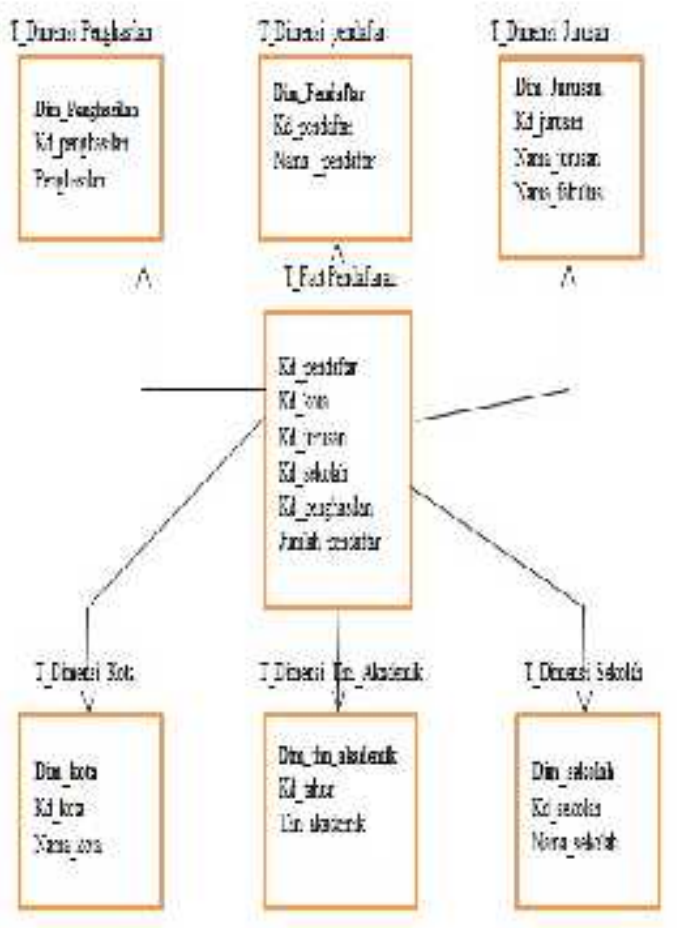

Gambar 3.2 Model Data Skema Bintang Data Warehouse Penunjang Strategi Promosi

Merujuk pada penelitian skema bintang (star schema) proses query lebih ringan dan memudahkan dalam penjelajahan terhadap data dimensi. Hal ini disebabkan karena tabel dimensi pada star schema tidak memerlukan tabel subdimensi.

Alasan penulis menggunakan pemodelan data warehouse skema bintang (star schema) diperkuat bahwa skema bintang (star schema) memiliki keuntungan sebagai berikut

a. Mudah dimengerti oleh pengguna (Professional IT) pengguna yang menggunakan data warehouse model skema bintang (star schema) mudah memahami query sehingga pengguna dapat mengetahui struktur database yang digunakan dalam data warehouse.

b. Navigasi yang optimal ((Optimizes Navigation) pada skema bintang (star schema) relasi data dapat digunakan untuk mengambil data dari suatu tabel ke tabel lain.

c. Sangat baik untuk pemrosesan query (Most suitable for query) memiiki kinerja yang sangat baik dalam pemrosesan query data.

\section{Model Perancangan perangkat analitik.}

Fungsi dari perangkat analitik yang berkaitan dengan penelitian penulis adalah perangkat lunak yang digunakan untuk menganalisis hasil dari data warehouse yang kemudian akan menghasilkan keluaran berupa informasi. Laporan grafik yang dapat dipakai sebagai penunjang pengambilan keputusan yang berkaitan dengan strategi promosi pada Universitas Banten Jaya. Perancangan arsitektur logis dapat terlihat pada gambar 3.4 


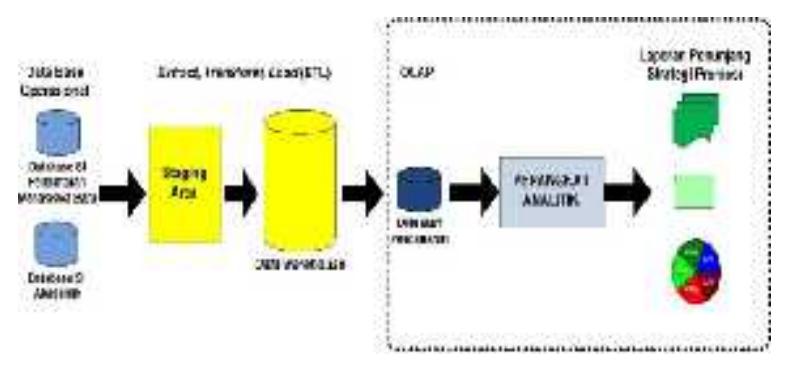

Gambar 3.5 Aritektur logis perangkat analitik pendaftaran Unbaja.

\section{Evaluasi terhadap data warehouse dan perangkat analitik}

Evaluasi terhadap struktur data warehouse dilakukan untuk memastikan kesesuaian antara rancangan data warehouse dan perangkat analitik yang sudah dibuat dengan implementasi pada DBMS SQL Server 2012, Micrososft Visual Studio 2010, dan PHP MySQL yang digunakan dalam implementasi perangkat analitik.

\section{Metode Analisis}

Metode analisis yang diterapkan dalam penelitian ini adalah dengan adanya ketersediaan data.

Data yang disimpan dalam data warehouse adalah data historis berorientasi objek yang dapat mendukung proses pengambilan keputusan bagi Manajemen. Artinya data tersebut harus kita susun sedemikian rupa sehingga dapat dianalisis menjadi berbagai informasi yang dibutuhkan manajemen saat proses pengambilan keputusan.

1. Mendefinisikan informasi-informasi apa saja yang dibutuhkan oleh kepala bagian akademik dan kemahasiswaan.

2. Menentukan measure dan dimension untuk semua informasi yang dibutuhkan manajemen. Measure adalah data numerik yang akan dicari jejak nilainya. Sedangkan dimension adalah parameter atau sudut pandang terhadap measure sehingga dapat mendefinisikan suatu transaksi.

3.Merancang suatu model yang dapat menggambarkan data atau tabel apa saja yang akan disimpan dalam data warehouse. Berikut keterhubungan antar tabel. Penulis menggunakan alat bantu pemodelan star schema akan menggambarkan fact table, yaitu tabel yang mempresentasikan measure sebagai pusat data.

\section{Analisa Perancangan Data Warehouse}

1. Analisis Data

a. Sumber Data

Sumber data yang digunakan dalam penelitian ini adalah database penerimaan mahasiswa dan akademik Universitas Banten Jaya. Dalam database yang ada berisi transaksional pendaftaran mahasiswa baru dan sedangkan system yang lain adalah system informasi akademik adalah data transaksional registrasi penerimaan mahasiswa baru. Data fakultas, jurusan, data sekolah, dan data jenis sekolah. Data tersebut kemudian di konversi ke dalam tipe lain yaitu format excel agar mudah untuk dilakukan data cleansing dan juga mudah pada saat ETL.

b. Metode Perancangan 
Metodologi perancangan Data Warehouse yang digunakan dalam penelitian ini menggunakan metode Nine-Step Methodology (Kimball, 2002) dalam metode ini terdapat Sembilan langkah dalam merancang sebuah data warehouse yaitu :

1. Memilih Proses (Choosing the process)

Proses yang terjadi dalam rancang bangun data warehouse ini meliputi jumlah pendaftar, jumlah yang mengikuti test grade dan jumlah , jumlah mahasiswa baru yang diterima.

2. Memilih Grain (Choosing the Grain)

Proses ini dilakukan setelah diketahui proses bisnis yang terjadi, Grain ini nantinya akan dijadikan sebagai fact table dalam data warehouse. Berdasarkan proses bisnis yang didefinisikan, grain yang dihasilkan meliputi: tahun akademik, kota, jurusan, sekolah, dan penghasilan orang tua pendaftar.

3. Mengidentifikasi dan penyesuaian dimensi (Identifying and Conforming the Dimension)

Langkah ketiga dalam perancangan data warehouse yaiutu identifikasi dimensi yang berhubungan dengan table fakta. Dari hasil identifikasi maka ditemukan dimensi yang terlibat meliputi :

1. Dimensi Tahun Akademik

2. Dimensi Kota

3. Dimensi Jurusan

4. Dimensi Sekolah

5. Dimensi Penghasilan

4. Memilih Fakta

Langkah berikutnya adalah memilih fact table berdasarkan pemilihan grain sebelumnya. Table fakta yang didapat dari analisis terdiri dari tahun akademik, kota, sekolah, jurusan dan penghasilan..rancangan fact table yang dihasilkan dalam penelitian ini adalah fact table pendaftaran.

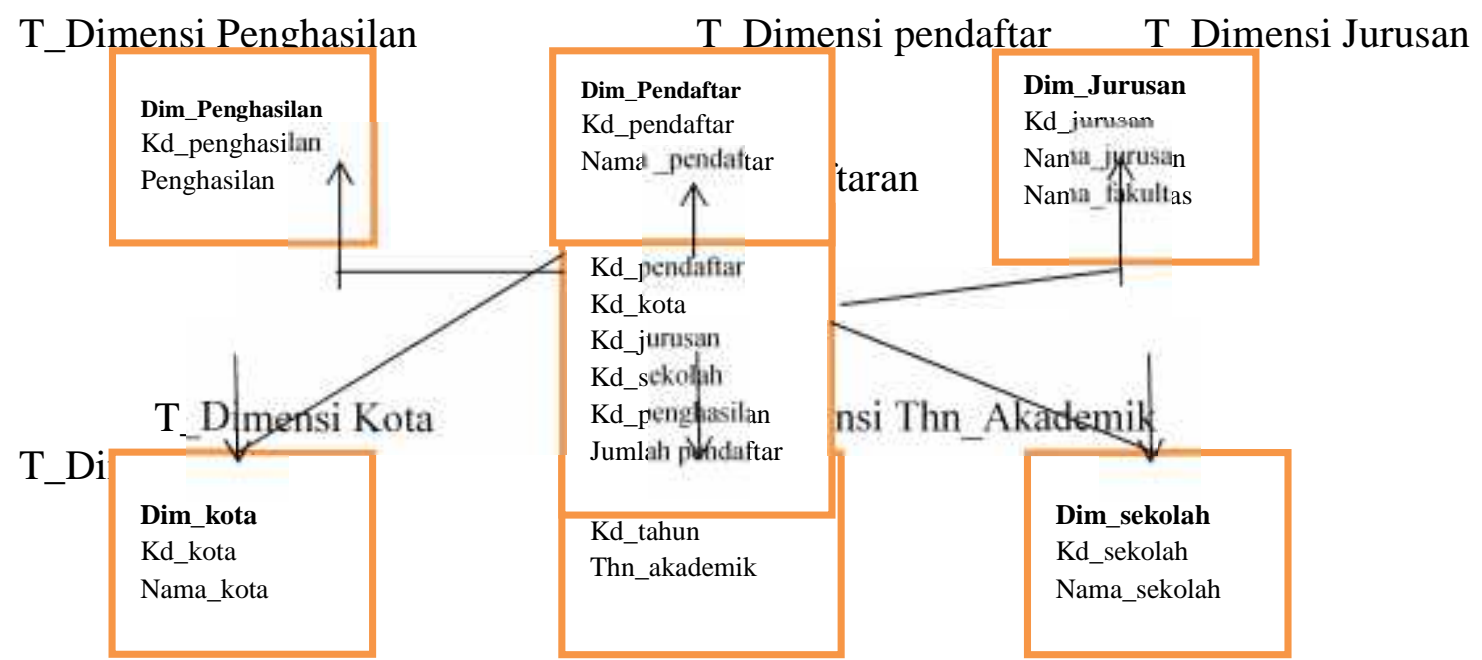

Tabel 4.1 Fact Tabel pendaftaran

5. Menyimpan pre-calculation dalam tabel fakta (storing pre-calculation in the fact table) Agregasi pada tabel fakta pendaftaran adalah total jumlah pendaftar berdasarkan tahun akademik.

6. Melengkapi tabel dimensi (Rounding out the dimension tables) 
Menambahkan sebanyak mungkin deskripsi teks pada tabel dimensi. Deskripsi tersebut harus intutif dan dapat dimengerti oleh pengguna. Tabel 4.2 berikut ini adalah merupakan deskripsi teks dari tabel dimensi.

Tabel 4.2 Tabel Rounding Out Dimensions

\begin{tabular}{|c|c|l|}
\hline Dimensi & Tabel & \multicolumn{1}{|c|}{ Deskripsi } \\
\hline $\begin{array}{c}\text { Tahun } \\
\text { Akademik }\end{array}$ & dim_tahun_akademik & $\begin{array}{l}\text { Laporan dapat ditinjau berdasarkan tahun } \\
\text { akademik pendaftaran mahasiswa baru. }\end{array}$ \\
\hline Kota & dim_kota & $\begin{array}{l}\text { Laporan dapat ditinjau berdasarkan } \\
\text { kota/kabupaten tertentu asal pendaftar. }\end{array}$ \\
\hline Jurusan & dim_jurusan & $\begin{array}{l}\text { Laporan dapat ditinjau berdasarkan } \\
\text { jurusan. }\end{array}$ \\
\hline Sekolah & dim_sekolah & $\begin{array}{l}\text { Laporan dapat ditinjau berdasarkan } \\
\text { sekolah dan jenis sekolah tertentu. }\end{array}$ \\
\hline Pendaftar & dim_pendaftar & $\begin{array}{l}\text { Laporan dapat ditinjau berdasarkan } \\
\text { pendaftar }\end{array}$ \\
\hline Penghasilan & Dim_penghasilan & $\begin{array}{l}\text { Laporan dapat ditinjau berdasarkan nilai } \\
\text { penghasilan orang tua pendaftar. }\end{array}$ \\
\hline
\end{tabular}

\section{Skema Data Warehouse}

Data yang disimpan dalam data warehouse adalah data historis berorientasi subjek yang dapat mendukung proses pengambilan keputusan bagi manajemen. Artinya data tersebut harus kita s s n sedemikian rupa sehingga dapat dianalisis menjadi berbagai informasi yang dibutuhkan manajemen saat proses pengambilan keputusan.

1. Mendefinisikan informasi-informasi apa saja yang dibutuhkan oleh Kepala Bagian Akademik dan kemahasiswaan.

2. Menentukan measure dan dimension untuk semua informasi yang dibutuhkan manajemen. Measure adalah data numerik yang akan dicari jejak nilainya, sedangkan dimensi $n$ adalah parameter atau sudut pandang terhadap measure sehingga dapat mendefinisikan suatu transaksi.

3. Merancang suatu model yang dapat menggambarkan data atau tabel apa saja yang akan disimpan dalam data warehouse, berikut keterhubungan antar tabel. Penulis menggunakan alat bantu pemodelan star schema (Skema bintang). Star schemaakan menggambarkan fact table, yaitu tabel yang merepresentasikan measure, sebagai "pusat data". Tabel ini nantinya akan terkoneksi dengan tabel-tabel yang mendeskripsikan dimensi untuk measure tersebut (dimension table).

\section{Proses ETL pada Data Warehouse}

Data yang digunakan dalam proses analisis ini terlebih dahulu melalui proses dumping dari database operasional dalam bentuk file excel. File-file tersebut seperti tampak pada gambar 4.3 


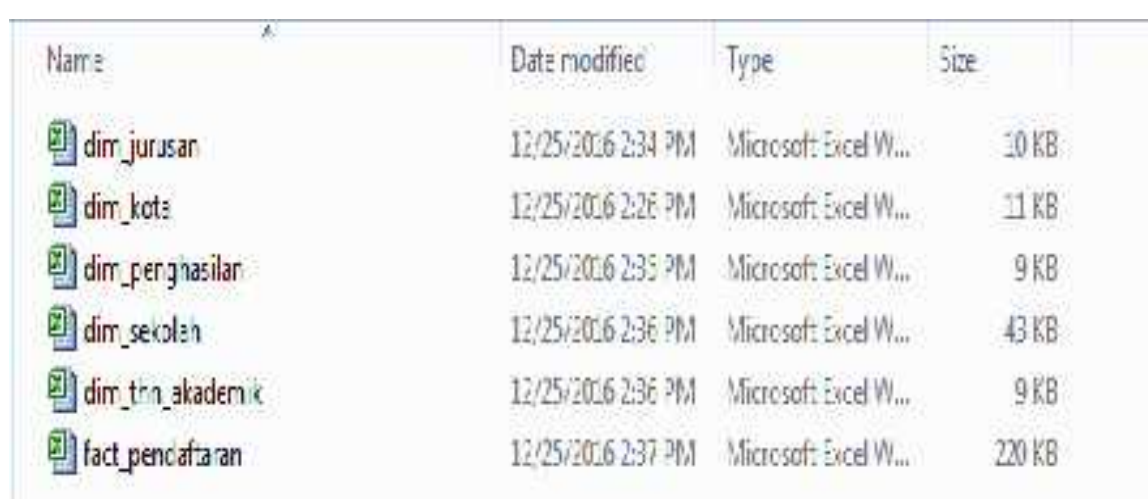

Gambar 4.3 File Hasil dumping dari database operasional

Karena data operasional/transaksional yang dihasilkan tidak terlepas dari kesalahankesalahan maka diperlukan proses clensing data. Proses data cleansing merupakan proses menghilangkan kesalahan-kesalahan yang ada pada data operasional/ transaksional. Proses sangat penting karena mempengaruhi hasil informasi yang akan dihasilkan dari data warehouse yang dibangun. Karena berpengaruh tentang Exstract, Transform, Load (ETL). Contoh kesalahan data operasional adalah seperti pada gambar 4.4 berikut ini. Nama kota yang sama namun berbeda penulisan satu record tanpa spasi yang lain menggunakan spasi.

\begin{tabular}{|c|c|c|}
\hline r kota & Jit oengher & kd jur: junser* \\
\hline TASIINALALIA & 500,000 & 55201 Tekriklnf \\
\hline TASIKNALAYN & $500,000-1$ & 22201 Tekrik Sif \\
\hline TASIKNALAYHA & 0 & 55201 Tekrik/nf \\
\hline TASIKNALAYA & 1 Jute-21 & 36233 Pendididic \\
\hline TASIKNALAYA & $500,000-1$ & 26211 Tekrik ln: \\
\hline LGSRMALAFA & 500,000 & 26201 Tekrik in: \\
\hline
\end{tabular}

Gambar 4.4 Contoh kesalahan Data Operasional

Setelah melewati proses data cleansing kemudian dilakukan proses ETL seperti dijelaskan pada sub bab. Detail pemrosesan ETL untuk tiap-tiap tabel dimensi dan fakta kemudian dijelaskan sebagai berikut :

\section{Dimensi Pendaftar}

Dimensi pendaftar dibentuk untuk memberikan kemampuan analisis terhadap pencapaian jumlah pendaftar ditinjau dari dimensi pendaftar.

Proses ETL untuk dimensi tahun pendaftar digambarkan pada gambar 4.5

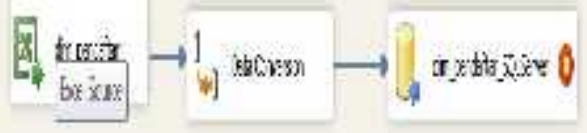

Gambar 4.5 Definisi proses ETL dimensi Pendaftar 
Hasil dari proses ETL dimensi pendaftar adalah struktur data fisik dimensi pendaftar sebanyak 3745 record

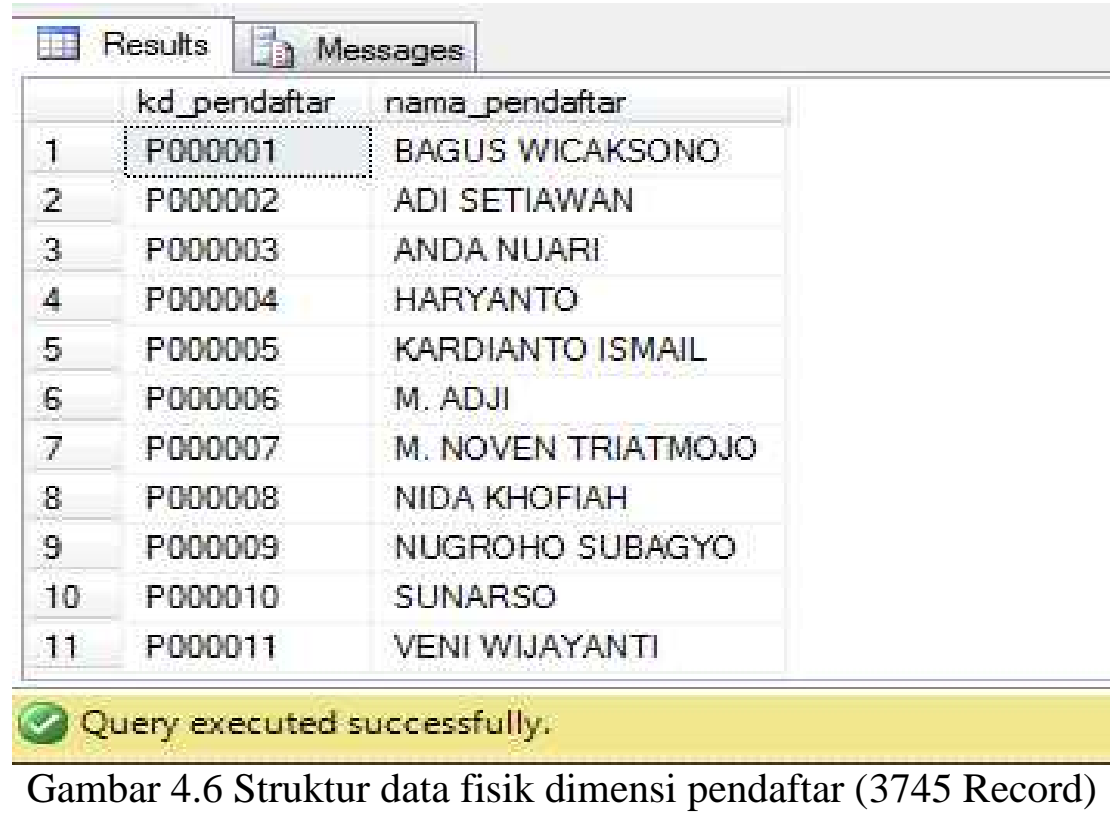

\section{Hasil dan Pembahasan}

Pengujian terhadap struktur data warehouse dilakukan untuk memastikan kesesuaian antara rancangan data warehouse yang sudah dibuat dengan implementasi pada DBMS SQL Server 2012 yang digunakan dalam implementasi sistem yang sebenarnya. Hasil implementasi pada DBMS SQL Server 2012.

Informasi jumlah calon mahasiswa baru pada Universitas Banten Jaya dapat dilihat dariberbagai dimensi (tahun akademik, kota, sekolah, jurusan, pendaftar, dan penghasilan orang tua) diinginkan ataupun dari dimensi-dimensi yang ada).

Perangkat analitik yang dirancang bangun hanya dipergunakan oleh bagian akademik Universitas Banten Jaya untuk menunjang strategi promosi penerimaan mahasiswa baru. Berdasarkan kebutuhan tersebut perangkat analitik yang dibangun tidak berbasis web namun berbasis dekstop. Berdasarkan hasil wawancara untuk memenuhi kebutuhan pengguna dari bagian akademik Universitas Banten Jaya, maka diputuskan untuk membentuk beberapa query yang berfungsi untuk visualisasi data yang dapat dianalisa.

\section{Evaluasi Data Warehouse dan Perangkat Analitik}

Evaluasi terhadap Data Warehouse dan perangkat analitik yang dibangun terdiri dari tahapan : uji coba data warehouse dan perangkat analitik.

Pengujian terhadap struktur data warehouse dilakukan untuk memastikan kesesuaian antara rancangan data warehouse yang sudah dibuat pada gambar 4.1 dengan implementasi pada DBMS SQL Server 2012 yang digunakan dalam implementasi sistem yang sebenarnya. Hasil implementasi pada DBMS SQL Server 2012 dapat dilihat pada gambar sedangkan perbandingan kesesuaiannyadapat dilihat pada tabel 5.3 dan tabel 5.4 







\begin{tabular}{|c|c|c|c|}
\hline & \begin{tabular}{|l|}
\multicolumn{1}{c}{ dim_jurusan } \\
$\begin{array}{l}\text { kd_jurusan } \\
\text { nama_fakultas } \\
\text { nama_jurusan }\end{array}$
\end{tabular} & & \\
\hline $\begin{array}{c}\text { Poin } \\
\text { Pengujian }\end{array}$ & Rancangan & Implementasi & Deskripsi \\
\hline $\begin{array}{l}\text { Dimensi } \\
\text { penghasilan }\end{array}$ & $\begin{array}{l}\text { Field : } \\
\text { Kd_penghasilan } \\
\text { Penghasilan } \\
\begin{array}{c}\text { dim_penghasilan } \\
\begin{array}{c}\text { \&d_penghasilan } \\
\text { penghasilan }\end{array}\end{array}\end{array}$ & 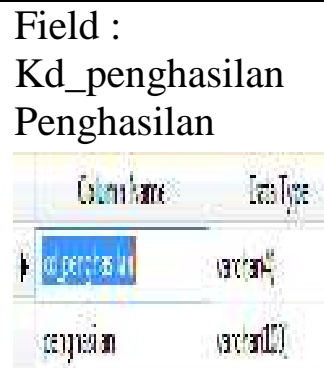 & $\begin{array}{l}\text { Tabel yang } \\
\text { mendefinisikan } \\
\text { dimensi } \\
\text { penghasilan }\end{array}$ \\
\hline $\begin{array}{c}\text { Poin } \\
\text { Pengujian }\end{array}$ & Rancangan & Implementasi & Deskripsi \\
\hline $\begin{array}{l}\text { Dimensi } \\
\text { Pendaftar }\end{array}$ & $\begin{array}{l}\text { Field : } \\
\text { Kd_pendaftar } \\
\text { Nama_pendaftar } \\
\begin{array}{l}\text { dim_pendaftar } \\
\begin{array}{l}\text { kd_pendaftar } \\
\text { Nama_pendaftar }\end{array}\end{array}\end{array}$ & 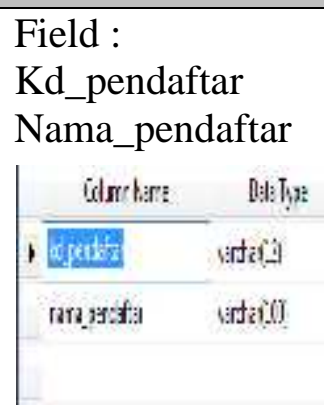 & $\begin{array}{l}\text { Tabel yang } \\
\text { mendefinisikan } \\
\text { dimensi } \\
\text { Pendaftar }\end{array}$ \\
\hline
\end{tabular}

Tabel 5.4 Tabel Perbandingan Struktur Rancangan dan Implementasi Tabel Fakta pada data Warehouse

\begin{tabular}{|l|l|l|l|}
\hline Poin Pengujian & \multicolumn{1}{|c|}{ Rancangan } & \multicolumn{1}{c|}{ Implementasi } & \multicolumn{1}{c|}{ Deskripsi } \\
\hline Fakta & Field : & Field : & Tabel yang \\
Pendaftaran & Kd_pendaftar & Kd_pendaftar & mendefinisikan \\
& Kd_tahun & Kd_tahun & fakta pendaftaran \\
& Nama_sekolah & Nama_sekolah & \\
& Kd_kota & Kd_kota & \\
& Kd_jurusan & Kd_jurusan & \\
& Jurusan & Jurusan & \\
& Kd_jenjang & Kd_jenjang & \\
& Id_pendaftar & Id_pendaftar & \\
& & & \\
& & & \\
& & & \\
\hline
\end{tabular}






\section{Uji Coba Terhadap Perangkat Analitik}

Pengujian terhadap perangkat analitik dilakukan untuk memastikan kemampuannya dalam menvisualisasikan informasi dari data dalam bentuk diagram-diagram yang diperlukan oleh kabag akademik dalam melihat pola data. Visualisasi yang dibuat yaitu visualisasi informasi jumlah pendaftar perdimensi yang digunakan. Kemudian perlu di uji dengan skenario yang sudah di definisikan seperti tampak pada tabel 5.5

\begin{tabular}{|c|c|}
\hline $\begin{array}{l}\text { Poin } \\
\text { pengujian }\end{array}$ & Hasil Pengujian \\
\hline $\begin{array}{l}\text { Visualisasi } \\
\text { Informasi } \\
\text { Jumlah } \\
\text { Pendaftar } \\
\text { per tahun } \\
\text { akademik }\end{array}$ & 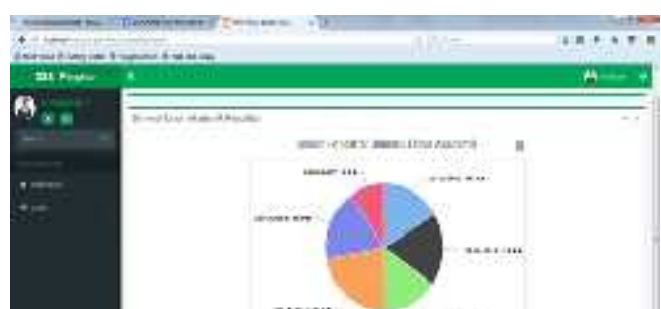 \\
\hline & 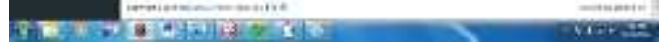 \\
\hline $\begin{array}{l}\text { Visualisasi } \\
\text { Informasi } \\
\text { Jumlah } \\
\text { Pendaftar } \\
\text { per Kota }\end{array}$ & 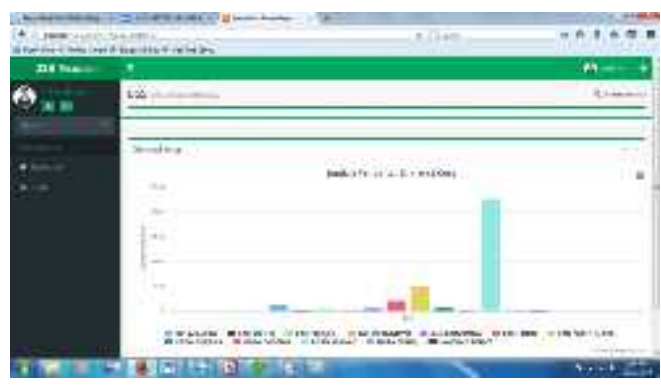 \\
\hline
\end{tabular}




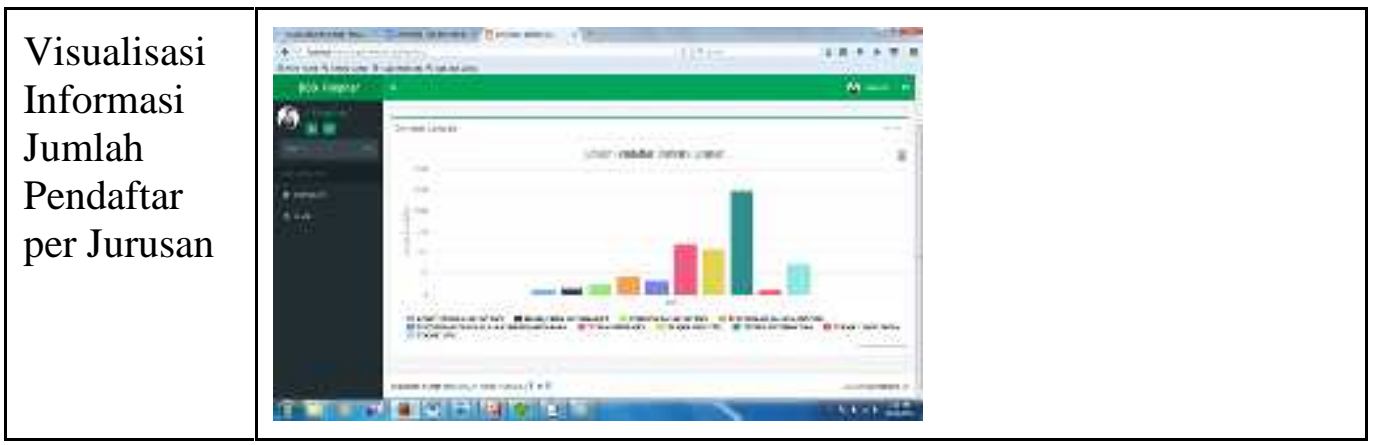

\section{Analisis Hasil Uji Coba Sistem}

Analisis hasil uji coba sistem dilakukan dengan membentuk matriks penilaian terhadap keberhasilan/kecocokan antara perilaku sistem yang diharapkan dan yang dilakukan setelah pengujian. Hal tersebut dijelaskan pada bagian berikutnya.

\section{Struktur Data Warehouse}

Karena seluruh item pengujian seperti tampak pada tabel 4.6 dinyatakan berhasil maka rancangan dan implementasi data warehouse dapat dikatakan sesuai kebutuhan yang diinginkan.

\section{Perangkat Analitik}

Karena seluruh item pengujian seperti tampak pada tabel dinyatakan berhasil maka perangkat analitik dapat dikatakan sudah mampu melakukan analisis dan filter dimensi, dan sudah memvisualisasikan menampilkan informasi yang dibutuhkan.

\section{Uji Penerimaan Pengguna}

Analisis uji penerimaan pengguna dilakukan dengan melakukan penyebaran angket yang bertujuan untuk mengukur respon pengguna kepada pihak-pihak yang berkepentingan terhadap perangkat analitik yang dibuat dalam penelitian ini. Berdasarkan wawancara dengan Kabag Akademik dan kemahasiswaan. Maka pihak-pihak yang ditunjuk untuk diberi angket adalah : Kabag Akademik dan Kemahasiswaan. Kasubbag Administrasi Akademik dan Kasubbag kerjasama dan kemahasiswaan.

Ada tiga kriteria utama yang diuji dalam angket respon yaitu :

1. Tampilan Program

2. Penggunaan Program

3. Informasi yang ditampilkan

Kriteria-kriteria tersebut kemudian dijabarkan dalam kriteria turunan yang dapat dilihat pada desain angket.

Setelah mendapatkan respon dari pengguna berdasarkan kriteria-kriteria yang ada, respon kemudian direkap untuk kemudian dilakukan analisis. Desain angket seperti terlihat pada gambar 5.8 dan rekap dari angket ditampilkan pada tabel 5.8 sampai dengan 5.10 
Tabel 5.8 Tabel hasil rekap respon pengguna untuk tampilan program

\begin{tabular}{|c|c|c|c|c|c|c|}
\hline \multirow[b]{2}{*}{ No } & \multirow[b]{2}{*}{ Kriteria } & \multicolumn{5}{|c|}{ Hasil } \\
\hline & & $\begin{array}{l}\text { Sangat } \\
\text { kurang }\end{array}$ & Kurang & Cukup & Baik & $\begin{array}{l}\text { Sangat } \\
\text { Baik }\end{array}$ \\
\hline 1. & Tata letak dashboard & & & & 3 & \\
\hline 2. & $\begin{array}{l}\text { Pengunaan warna untuk } \\
\text { tampilan utama }\end{array}$ & & & 1 & 2 & \\
\hline 3. & $\begin{array}{lr}\text { Penggunaan } & \text { warna } \\
\text { untuk bagian filter } \\
\text { dimensi }\end{array}$ & & & 2 & 1 & \\
\hline 4. & 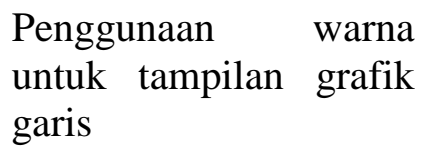 & & & & 3 & \\
\hline 5. & $\begin{array}{ll}\text { Penggunaan } & \text { warna } \\
\text { untuk tampilan } & \text { grafik } \\
\text { batang } & \end{array}$ & & & & 3 & \\
\hline 6. & 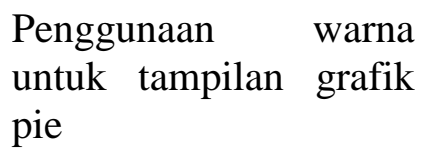 & & & & 3 & \\
\hline 7. & 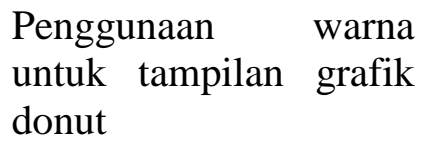 & & & & 3 & \\
\hline 8. & $\begin{array}{l}\text { Penggunaan warna } \\
\text { untuk pivot tabel }\end{array}$ & & & 2 & & 1 \\
\hline
\end{tabular}

Tabel 5.9 Tabel hasil rekap respon pengguna untuk pengguna program

\begin{tabular}{|l|l|l|l|l|l|l|}
\hline \multirow{2}{*}{ No } & \multicolumn{2}{|c|}{ Kriteria } & \multicolumn{4}{|c|}{ Hasil } \\
\cline { 3 - 7 } & $\begin{array}{l}\text { Sangat } \\
\text { kurang }\end{array}$ & Kurang & Cukup & Baik & $\begin{array}{l}\text { Sangat } \\
\text { Baik }\end{array}$ \\
\hline 1. & Kemudahan login & & & 2 & 1 & \\
\hline 2. & $\begin{array}{l}\text { Kemudahan } \\
\text { menggunakan fasilitas } \\
\text { filtering dimensi }\end{array}$ & & & 1 & 2 & \\
\hline 3. & $\begin{array}{l}\text { Kemudahan mencetak } \\
\text { tampilan grafik }\end{array}$ & & & & & 1 \\
\hline
\end{tabular}


Tabel 5.10 tabel hasil rekap respon pengguna untuk informasi yang ditampilkan

\begin{tabular}{|c|c|c|c|c|c|c|}
\hline \multirow[b]{2}{*}{ No } & \multirow[b]{2}{*}{ Kriteria } & \multicolumn{5}{|c|}{ Hasil } \\
\hline & & $\begin{array}{l}\text { Sangat } \\
\text { kurang }\end{array}$ & Kurang & Cukup & Baik & $\begin{array}{l}\text { Sangat } \\
\text { Baik }\end{array}$ \\
\hline 1. & $\begin{array}{lr}\text { Kejelasan } & \text { representasi } \\
\text { informasi } & \text { jumlah } \\
\text { pendaftar } & \end{array}$ & & & 1 & 2 & \\
\hline 2. & $\begin{array}{lr}\text { Kejelasan } & \text { representasi } \\
\text { informasi } & \text { persen } \\
\text { pendaftar } & \end{array}$ & & & 1 & 2 & \\
\hline 3. & $\begin{array}{lr}\text { Kejelasan } & \text { representasi } \\
\text { informasi } & \text { untuk } \\
\text { penunjang } & \text { strategi } \\
\text { promosi } & \end{array}$ & & & & 2 & 1 \\
\hline
\end{tabular}

\section{Analisis Hasil Uji Coba Penerimaan Pengguna}

Berdasarkan respon dari pengguna yang telah didapatkan, maka dapat dilakukan analisis terhadap penerimaan pengguna. Untuk itu perlu dilakukan penskalaan terlebih dahulu sebagai berikut :
1. Sangat kurang
$:-2$
2. Kurang
$:-1$
3. Cukup
$: 0$
4. Baik
$: 1$
5. Sangat Baik
$: 2$

Rekap hasil secara keseluruhan untuk tiap kriteria adalah seperti pada tabel 5.12.

Tabel 5.12 tabel rangkuman hasil kuesioner

\begin{tabular}{|l|l|l|l|l|l|l|}
\hline \multirow{2}{*}{ No } & \multicolumn{2}{|c|}{ Kriteria } & \multicolumn{5}{|c|}{ Hasil } \\
\cline { 3 - 7 } & & $\begin{array}{l}\text { Sangat } \\
\text { kurang }\end{array}$ & Kurang & Cukup & Baik & $\begin{array}{l}\text { Sangat } \\
\text { Baik }\end{array}$ \\
\hline 1. & Tampilan program & & & 5 & 18 & 1 \\
\hline 2. & Penggunaan Program & & & 3 & 15 & 1 \\
\hline 3. & $\begin{array}{l}\text { Informasi } \\
\text { ditampilkan }\end{array}$ & & 2 & 6 & 1 \\
\hline
\end{tabular}

Analisis untuk hasil tersebut adalah sebagai berikut : 


\section{Tampilan Program}

Bobot skala untuk tampilan program adalah : $((0 \times 5)+(1 \times 8)+(2 \times 1)) / 24=0,83$.

Karena penilaian untuk tampilan program untuk pengguna menghasilkan 0,83 berarti pengguna menerima dengan baik tampilan program yang diimplementasikan karena angka maksimal perhitungan adalah 1

2. Penggunaan Program

Bobot skala untuk penggunaan program adalah : $((0 \times 3)+(1 \times 5)+(2 \times 1)) / 9=0,78$.

Hasil penilaian untuk penggunaan program oleh pengguna juga yaitu 0,78 karena angka maksimal dari perhitungan adalah 1 dapat disimpulkan bahwa pengguna tidak mengalami kesulitan pengopersian program.

3. Informasi yang ditampilkan

Bobot skala untuk informasi yang ditampilkan adalah $((0 \times 2)+(1 \times 6)+(2 \times 1)) / 9=$ 0,89 . Hasil penilaian untuk kriteria ini cukup jelas, yaitu baik dengan angka 0,89 . karena kriteria ini merupakan point penilaian pengguna yang terpenting, dan hasilnya baik maka kemampuan sistem menyampaikan informasi yang dibutuhkan pengguna dapat dinyatakan sudah sesuai kebutuhan pengguna.

\section{Kesimpulan}

Kesimpulan yang dihasilkan dari penelitian Rancang Bangun Data Warehouse Dan Perangkat Analitik Sebagai Penunjang Strategi Promosi pada universitas banten jaya ini sebagai berikut :

1. Rancang bangun data warehouse dan perangkat analitik sebagai penunjang strategi promosi cukup bermanfaat gunapengolahan data dalam jumlah yang cukup besar, sehingga diharapkankebutuhan dan informasi mengenai strategi promosi penerimaan mahasiswa baru dapat dipenuhi.

2. Data warehouse dan perangkat analitik sebagai penunjang strategi promosi dapat dipergunakan untukmenganalisa data siswa baru sehingga didapat informasi jumlah pendaftar pada Universitas Banten Jaya dari berbagai dimensi (Tahun Akademik, Kota, sekolah, Jurusan, pendaftar dan penghasilan orang tua. Telah dievaluasi kemanfaatan Rancang Bangun Data Warehouse Dan Perangkat Analitik yang dikembangkan memberikan manfaat-manfaat yaitu visualisasi jumlah pendaftar pertahun akademik, perkota asal pendaftar, per sekolah asal pendaftar, per penghasilan orang tua pendaftar, perjurusan yang dipilh pendaftar. Perangkat analitik dibuat memiliki fitur-fitur lain yang dapat menunjang dalam melakukan strategi promosi.

Data sumber dari data warehouse sangatlah penting, semakin banyak kesalahan data sumber maka membutuhkan waktu yang banyak pula untuk proses cleansing atau pembersihan data. Pada penelitian ini kesalahan data pada data sumber pendaftaran relatif banyak sehingga memakan waktu yang relatif banyak pula. Alat yang digunakan yaitu Microsoft Excell dengan teknik Replace dan Vlookup.

\section{Saran}

Saran yang dapat diberikan agar dapat memperoleh hasil yang lebih baik dan bermanfaat, yaitu :

1. Pengembangan aplikasi yang telah ada, sehingga data-data dalam jumlah besar lebih terorganisir, terkelompok dan lebih mudah diproses guna 
meningkatkan pelayanan publik, yang dalam hal ini adalah pendaftar mahasiswa baru pada Universitas Banten Jaya.

2. Perancangan data warehouse yang ada diharapkan dapat iimplementasikandan diperluas cakupannya, sehingga mencakupi berbagai bidang lainnya pada Universitas Banten Jaya.

\section{DAFTAR PUSTAKA}

[1] Arifin, Kusrini, And E. T. Luthfi, "Perancangan Dan Implementasi Data Warehouse Pemasaran Pada CV. Diandra Prima Mitra Media Yogyakarta," 2014.

[2] B. K. Seah, "An Application Of A Healthcare Data Warehouse System," ThirdInt.Conf. Innov.Comput. Technol. (Intech 2013), Pp. 269-273, Aug.2013.

[3] B. Verhage, Marketing Fundamentals. 2010.

[4] C. Vercellis, Business Intelligence; Data Mining And Optimization ForDecision Making. 2009.

[5] D. K. Widyawati, "Perancangan Struktur Data Warehouse Untuk Mendukung Perencanaan Pemasaran Produk Menggunakan Star Schema,” Vol. 6, No. 3, 2012.

[6] E. Miranda, "Perancangan Model Data Warehouse Dan Perangkat Analitik Untuk Memaksimalkan Proses Pemasaran Hotel $\square$ : Studi Kasus Pada Hotel Abc," Comtech, Vol. 4, No. 1, P. 230-239, 2013.

[7] Ir. Agustina Shinta, Manajemen Pemasaran, Pertama. Ub Press, 2011, P. 156.

[8] J. Guerra, C. Architect, And D. Andrews, "Why You Need A Data Warehouse,"2013.

[9] L. L. Reeves, A Manager's Guideo Data Warehouse. 2009.

[10] M. Sethi, "Data Warehousing And Olap Technology," Vol. 2, No. 2, Pp. 955-960, 2012.

[11] P. Kotler And G. Armstrong, Principles Of Marketing. 2011, P. 740.

[12] Sarka, Dejan, M. Lah, And G. Jerkic, Designing And Implementing A DataWarehouse. 2012, P. 848.

[13] T. Ahmed, T. B. Pedersen, And H. Lu, "A Data Warehouse Solution For A Alyzing Rfid-Based Baggage Tracking Data," (C) 2013 Ieee , Pp. 283- 292, Jun. 2013.

[14] Y. Zhang, J. Liu, And W. Xu, "Design And Implementation Of Central Heating Data Warehouse System,” Pp. 365-368, 2013. 